This is the author's version of a work that was accepted for publication in Atmospheric environment (ed. Elsevier). Changes resulting from the publishing process, such as peer review, editing, corrections, structural formatting, and other quality control mechanisms may not be reflected in this document. Changes may have been made to this work since it was submitted for publication. A definitive version was subsequently published in Atmospheric environment, vol. 191 (Oct. 2018), p. 105-115. (C) 2018. This manuscript version is made available under the CC-BY-NC-ND 4.0 license http://creativecommons.org/licenses/by-nc-nd/4.0/

DOI 10.1016/j.atmosenv.2018.08.010 


\title{
Seasonal and diurnal variations of plant isoprenoid emissions from two dominant species in Mediterranean shrubland and forest submitted to experimental drought
}

\author{
Zhaobin $\mathrm{Mu}^{1,2}$, Joan Llusià ${ }^{1,2}$, Daijun Liu ${ }^{1,2}$, Romà Ogaya ${ }^{1,2}$, Dolores Asensio ${ }^{1,2}$, Chao Zhang ${ }^{1,2}$, Josep \\ Peñuelas ${ }^{1,2}$
}

${ }^{1}$ CSIC, Global Ecology Unit CREAF-CSIC-UAB, E08193 Bellaterra, Catalonia, Spain

${ }^{2}$ CREAF, E08193 Cerdanyola, Catalonia, Spain

\begin{abstract}
We tested the effect of increasing drought conditions in the Mediterranean Basin on isoprenoid emissions for the coming decades by analyzing their effect experimentally on the dominant Mediterranean species Erica multiflora in a Garraf shrubland and Quercus ilex in a Prades forest in Catalonia (Spain). Drought was simulated in Garraf using automatically sliding curtains to decrease the amount of soil moisture by $5 \%$ and in Prades by partial rainfall exclusion and runoff exclusion for a $25 \%$ decrease. We measured photosynthetic rates $(A)$, stomatal conductance $\left(\mathrm{g}_{\mathrm{s}}\right)$ and rates of isoprenoid emission in the morning and at midday for four seasons and determined the relationship of emission rates with environmental conditions. Terpenes were emitted by both species, but only E. multiflora emitted isoprene. $\alpha$-Pinene and limonene were the most abundant terpenes. Isoprenoid emissions increased with air temperature and generally decreased as the amount of soil moisture increased. The results of this study suggest that higher isoprenoid emissions can be expected in the warmer and drier conditions predicted for the coming decades in the Mediterranean region.
\end{abstract}

Keywords Mediterranean ecosystems; Experimental drought; Seasonal variations; Diurnal variations; BVOC emissions; Isoprenoids; Erica multiflora; Quercus ilex.

\section{Introduction}

Mediterranean-type ecosystems provide important ecological services, such as the conservation of biodiversity and nutrient cycling (Peñuelas et al., 2013; Seddon et al., 2016). Precipitation is low for these ecosystems, especially in hot periods, and climate change has contributed to the increasing drought in recent decades (Llusià et al., 2011). Models of global circulation, climate and ecophysiology predict a further reduction in the availability of water in Mediterranean regions around the world (Piñol et al., 1998; IPCC, 2007; Sabaté, et al., 2002; Peñuelas and Boada, 2003), which are naturally water-limited (Sardans and Peñuelas, 2007) due to the high temperatures and the consequent high rates of evapotranspiration (Peñuelas and Llusià, 2001). Drought stress can affect numerous physiological and biochemical processes governing plant growth, leading to a reduction in stem elongation, leaf expansion and stomatal conductance (Daie and Patrick, 1988; Alexieva et al., 2001; Liu et al., 2016). Plants, however, can survive these hydropenic stress conditions after long periods of acclimation (Chaves et al., 2002; Bai et al., 2008; Rubio-Casal et al., 2010) by adjusting their metabolism (Hsiao, 1973) and reorganizing their energy resources (Dobrota, 2006), including changes in photosynthetic rate $(\mathrm{A})$ and stomatal conductance $\left(\mathrm{g}_{\mathrm{s}}\right)$. Biogenic volatile organic 
compounds (BVOCs) are also an important tool for resisting drought (Peñuelas and Llusià, 2003; Filella et al., 2007; Porcar-Castell et al., 2009).

Approximately half of all plant species growing in Mediterranean-type ecosystems, especially shrubland and forest ecosystems, produce and emit a large variety of BVOCs (Peñuelas and Llusià, 1999). These compounds are formed in various plant organs such as flowers, fruits, leaves, bark and roots (Niederbacher et al., 2015) during diverse physiological processes (Laothawornkitkul et al., 2009), which are then emitted directly or stored in specialized structures (Loreto and Schnitzler, 2010). BVOCs provide protection against high temperatures, high irradiation, oxidative stress and drought stress (Velikova et al., 2005; Holopainen and Gershenzon, 2010; Loreto and Schnitzler, 2010). They can also act as herbivore deterrents, attractants of pollinators and enemies of herbivores (Peñuelas and Munné-Bosch, 2005; Llusià and Peñuelas, 2000) and plant-plant communication signals (Peñuelas and Llusià, 2003). BVOCs are thus a vital and central component of plants due to their significance to the survival of individual plants but in addition they exert a strong influence on atmospheric chemistry (Dicke and Loreto, 2010; Seco et al., 2013; Niederbacher et al., 2015). BVOCs play a key role in atmospheric processes that influence the atmospheric burden of pollutants (Kroll and Seinfeld, 2008), which can also interact with climate change in several ways (Peñuelas and Llusià, 2003; Yuan et al., 2009; Riipinen et al., 2012). BVOCs are the main biogenic precursors of ozone and by consuming hydroxyl radical prolong the persistence of other compounds such as the greenhouse gas methane (Di Carlo et al., 2004). Furthermore, the photo-oxidation of BVOCs generates secondary organic aerosols, which have the potential for complex climatic feedbacks (Claeys et al., 2004; Carslaw et al., 2009).

BVOCs are very diverse and consist of various organic classes such as isoprenoids, fatty acid derivatives, alcohols, alkanes, alkenes, esters and acids (Kreuzwieser et al., 1999; Peñuelas and Llusià, 2001). Isoprenoids such as isoprene and monoterpenes, the most common and abundant BVOCs, confer protection against the high temperatures and drought stress under the current trend of climatic warming (Peñuelas and Llusià, 2001; Copolovici et al., 2005).

Several studies have demonstrated the importance of abiotic and biotic factors for the emissions of BVOCs (Peñuelas and Llusià, 2001 and 2003; Paris et al., 2010). Among abiotic factors, water availability has a strong effect on BVOC emission, especially under Mediterranean conditions characterized by long dry summers with high solar irradiation and temperatures (Tsakiris et al., 2007; Llusià et al., 2011 and 2013). Plant behavior is complex under these integrated environmental influences and may differ among biological species. Rates of isoprenoid emission increase and help plants to resist stress under moderate drought conditions but decrease under severe drought conditions (Gershenzon et al., 1978; Llusià et al., 2011 and 2013; Hansen and Seufert, 1999).

The dominant tree species in the Mediterranean Basin have two patterns of terpene emission depending on if they have the ability to store terpenes (Lerdau et al., 1997; Llusià and Peñuelas, 2000). Pool size in resin ducts and internal or external glands in terpene-storing species (Lerdau et al., 1997; Peñuelas and Llusià, 2001; Llusià et al., 2014) affect emission rates, and the short-term response of terpene-emission rates to photosynthetic rates may be stronger and faster in non-storing than storing species (Gershenzon et al., 1978; Staudt and Seufert, 1995). Terpene-emission rates in terpene-storing plants, though, are not necessarily determined by terpene concentration; their response to drought can be involved in the short- 
term control of emissions, either increasing (Rennenberg et al., 2006) or decreasing (Bertin and Staudt, 1996; Llusià et al., 2006) the emission rates depending on the intensity of the water stress (Llusià and Peñuelas, 2000; Llusià et al., 2011).

Climatic experiments have been widely used on various time scales to predict the potential physiological and phenological changes in plants under simulated future climatic scenarios (Beier et al., 2012; Leuzinger et al., 2011; De Boeck et al., 2015; Ogaya et al., 2014). Numerous field experiments in various ecosystems have demonstrated the effectiveness of identifying the physiological adjustments of plants in response to climate change, despite the variety and complexity of the environmental conditions (Prieto et al., 2009; Limousin et al., 2010; Liu et al., 2016). The short-term diurnal (Peñuelas and Llusià, 1999) and long-term seasonal (Guenther, 1997; Llusià and Peñuelas, 2000) cycles under experimental drought also determine the status of isoprenoid emission (Llusià and Peñuelas, 2000; Llusià et al., 2006). Variations in emissions have been linked to corresponding changes in temperature, radiation, air humidity and water availability (Llusià et al., 2006) but also to leaf development and physiological activity (Llusià and Peñuelas, 2000). These factors are also involved in the variations among isoprenoids due to their diverse physicochemical traits (Llusià and Peñuelas, 2000).

We studied the net photosynthetic rates (A), the stomatal conductance $\left(\mathrm{g}_{\mathrm{s}}\right)$ and the rates of isoprenoid emissions in the shrub Erica multiflora L. and the tree Quercus ilex L., which are widely distributed in the western and central Mediterranean Basin and are among the dominant species at our two study sites, Garraf (shrubland) and Prades (forest), respectively (Llusià et al., 2006 and 2013; Ogaya et al., 2014). Our aims were to determine the relationship between plant physiology and abiotic factors under Mediterranean field conditions, especially gas exchange and isoprenoid emissions, for predicting the effects of increasing drought stress expected in the coming decades and to improve the algorithms for isoprenoid emission used in models.

\section{Material and methods}

\subsection{Study sites and species descriptions}

The study was carried out in the Garraf and Prades Mountains in Catalonia, northeastern Spain. The climate and vegetation at the two sites are typically Mediterranean. Annual rainfalls were $510.2 \mathrm{~mm}$ in Garraf and $661.4 \mathrm{~mm}$ in Prades during the measurement year.

Garraf Natural Park is a dry shrubland (Rosmarino-Ericion) south of Barcelona $\left(41^{\circ} 18^{\prime} 08^{\prime \prime} \mathrm{N}, 1^{\circ} 49^{\prime} 05^{\prime \prime} \mathrm{E}\right.$; $210 \mathrm{~m}$ a.s.1.). This site suffered large fires in the summers of 1982 and 1994, the regenerated vegetation has a coverage of 50-60\% and a maximum height of $70 \mathrm{~cm}$. The dominant species at the study site are Erica multiflora L., Globularia alypum L., Pinus halepensis L. and Rosmarinus officinalis L. (Llusià et al., 2006 and 2013). All are common evergreens of the coastal shrubland in the western Mediterranean Basin. We chose one dominant species Erica multiflora L. as research object in this site.

The Prades Mountains are in southwestern Catalonia $\left(41^{\circ} 20^{\prime} 42^{\prime \prime} \mathrm{N}, 1^{\circ} 02^{\prime} 04^{\prime \prime} \mathrm{E} ; 970 \mathrm{~m}\right.$ a.s.1.) and about $30 \mathrm{~km}$ from the Mediterranean coast. The Prades sampling site is a holm oak forest with tree heights between 1.5 and 10 m, dominated by Quercus ilex (Bolòs and Vigo, 1990; Llusià et al., 2013; Ogaya et al., 2014). The site contains other important evergreen tree and shrub species (Phillyrea latifolia L., Arbutus unedo L., Pinus sylvestris L., Erica arborea L. and Juniperus oxycedrus L.) and deciduous species such as 
Sorbus torminalis L. and Acer monspessulanum L. (Llusià et al., 2013). We chose the dominant species Quercus ilex as research object in this site.

\subsection{Experimental design}

The drought experiments were carried out from 1999 to 2014 (16 years) for both sites. In Garraf, six plots $(5 \times 4 \mathrm{~m})$ were randomly organized in three blocks for replication, with each block having one drought and one control plot. Transparent and waterproof plastic curtains were activated in the drought treatments by rain sensors to cover the plants and soil during rain for four seasons. Control plots had the same scaffolding but without the curtains. All measurements were conducted in the central $12 \mathrm{~m}^{2}$ to reduce margin effects. The outer $0.5 \mathrm{~m}$ of each plot served as an open buffer zone.

In Prades, four plots $(15 \times 10 \mathrm{~m})$ were delimited at the same altitude along the slope, two as drought and two as control plots. The drought treatment consisted of partial rain exclusion using PVC strips suspended 0.5-0.8 m above the soil covering approximately $30 \%$ of the total plot surface. A ditch $0.8 \mathrm{~m}$ deep was excavated along the entire top edge of the drought plots to intercept runoff water.

Emissions were measured in winter 2014 (12, 13 and 14 February in Garraf and 23, 24 and 25 January in Prades), spring 2014 (1, 2 and 3 May in Garraf and 14, 15 and 16 May in Prades), summer 2014 (5, 7 and 9 August in Garraf and 29, 30 and 31 July in Prades) and autumn 2014 (29 and 30 October and 1 November in Garraf and 21, 22 and 23 October in Prades) in the morning (9:00-13:00 solar time) and at midday (13:00-17:00 solar time). Emissions from sunlit and healthy E. multiflora needle clusters and $Q$. ilex leaves were measured from three random plants in each plot. Air temperature was measured by an automatic meteorological station, and soil moisture was measured by time domain reflectometry (Tektronix 1502C, Beaverton, United States), both about every 30 min on the day of sampling.

\subsection{Gas-exchange measurements and sampling of isoprenoid emissions}

$A$ and $g_{s}$ were measured and isoprenoid emissions were collected simultaneously using a Licor-6400XT (4647 Superior Street P.O. Box 4425 Lincoln, Nebraska USA) gas-exchange system. A and $\mathrm{g}_{\mathrm{s}}$ were measured at a quantum flux density of $1080 \pm 19 \mu \mathrm{mol} \mathrm{m}^{-2} \mathrm{~s}^{-1}$ under a controlled $\mathrm{CO}_{2}$ concentration of 400 $\pm 2 \mathrm{ppm}$. One E. multiflora needle cluster or one $Q$. ilex leaf was enclosed in a clamp-on gas-exchange cuvette with a surface area of $2 \mathrm{~cm}^{2}$. The isoprenoids were collected by pumping air which was generated using a Qmax air-sampling pump (Supelco, Bellefonte, USA) from the cuvette through a glass cartridge (8 $\mathrm{cm}$ long and $0.3 \mathrm{~cm}$ internal diameter). Sampling time was $10 \mathrm{~min}$, and the flow was about $400 \mathrm{~mL} \mathrm{~min}^{-1}$. The cartridges were manually filled with adsorbents Carbotrap B, Carboxen 1003 and Carbopack Y (Supelco, Bellefonte, Pennsylvania) separated by plugs of quartz wool. The hydrophobic properties of the activated adsorbents minimized any sample displacement by water, without chemical transformation in the tube. Isoprenoid concentrations were determined by reference to trapped standards ( $\alpha$-pinene, $\beta$-pinene, 3 carene, camphene, myrcene, limonene, sabinene, camphor and dodecane). The tubes were conditioned before terpene sampling with a stream of purified helium for $35 \mathrm{~min}$ at $350^{\circ} \mathrm{C}$. The trapping and desorption efficiencies of liquid and volatilized standards such as $\alpha$-pinene, 3 -carene or limonene (the main terpenes accounting for about $65-85 \%$ of total emission) were practically $100 \%$. Blank samples of air without leaves in the cuvette were collected for 10 min immediately before each measurement. Sampled leaves were cut 
and stored in a portable cooler box at $4{ }^{\circ} \mathrm{C}$ and taken to the laboratory where they were oven-dried at $60{ }^{\circ} \mathrm{C}$ to constant weights. The metallic tubes (with trapped BVOCs) were stored at $-22{ }^{\circ} \mathrm{C}$ until analysis.

\subsection{Isoprenoid analyses}

The isoprenoids were analyzed using a GC-MS system (HP59822B, Hewlett Packard, Palo Alto, USA) with an automatic sample processor (Combi PAL, FOCUS-ATAS GL International BV 5500 AA Veldhoven, The Netherlands). The desorber was an OPTIC3 injector (ATAS GL International BV 5500 AA Veldhoven, The Netherlands), and the temperature was increased at $16{ }^{\circ} \mathrm{C} \mathrm{s}^{-1}$ from $60{ }^{\circ} \mathrm{C}$ to $300{ }^{\circ} \mathrm{C}$. The desorbed isoprenoids were cryofocused at $-20{ }^{\circ} \mathrm{C}$ for 2 min after which the cryotrap was heated rapidly to $250^{\circ} \mathrm{C}$, and conducted into a $30 \mathrm{~m} \times 0.25 \mathrm{~mm} \times 0.25 \mu \mathrm{m}$ film capillary column (HP-5, Crosslinked $5 \%$ pH Me Silicone; Supelco, Bellefonte, USA). The flow of helium was $1 \mathrm{~mL} \mathrm{~min}^{-1}$, and the total run time was $29 \mathrm{~min}$ including the solvent delay for about $4 \mathrm{~min}$. The initial oven temperature was increased at $30{ }^{\circ} \mathrm{C}$ $\min ^{-1}$ from 40 to $60{ }^{\circ} \mathrm{C}$ and then at $10{ }^{\circ} \mathrm{C} \min ^{-1}$ to $150{ }^{\circ} \mathrm{C}$, maintained for $3 \mathrm{~min}$, increased at $70{ }^{\circ} \mathrm{C} \min ^{-1}$ to $250{ }^{\circ} \mathrm{C}$ and maintained for another $5 \mathrm{~min}$.

The monoterpenes were identified by comparing their retention times with those of standards from Fluka (Buchs, Switzerland), published spectra, GCD ChemStation G1074A HP and the Wiley7n mass-spectra library. Terpene concentrations were determined from calibration curves for common terpenes such as $\alpha$ -

pinene, 3-carene, $\beta$-pinene, myrcene, limonene, sabinene and $\alpha$-humulene, every five analyses using three terpene concentrations (always $r^{2}>0.99$ for the relationships between the signal and terpene concentrations). The most abundant terpenes had very similar sensitivities, with differences $<5 \%$ among the calibration factors.

\subsection{Statistical analyses}

The ANOVAs were conducted using STATISTICA v.8.0 for Windows (StatSoft, Inc. Tulsa, USA). Statistical differences between treatments were analyzed with a Student's $t$-test. Differences were considered significant at $P<0.05$. The analysis of the effects of season, treatment and sampling time were conducted by repeated measurements ANOVA. Regression analyses were conducted using Sigma Plot v. 11.0 for Windows (Systat Software, Chicago, USA).

\section{Results}

3.1. Seasonal and diurnal variation of air temperature and soil moisture

Mean air temperature on the sampling dates in Garraf ranged between $14.7 \pm 1.17^{\circ} \mathrm{C}$ in winter mornings and $35.3 \pm 0.51{ }^{\circ} \mathrm{C}$ at summer middays. Soil moisture ranged between $7.2 \pm 0.33 \%(\mathrm{v} / \mathrm{v})$ at summer middays and $24.7 \pm 1.40 \%(\mathrm{v} / \mathrm{v})$ in winter mornings (Fig. 1). Compared to control treatment, the drought treatment decreased soil moisture an average of $3.7 \%$ in mornings and $4.7 \%$ at midday throughout the year, with decreases ranging between $1.3 \%$ in winter mornings and $14.7 \%$ in spring afternoons.

Mean air temperature on the sampling dates in Prades ranged between $9.4 \pm 0.84{ }^{\circ} \mathrm{C}$ in winter mornings and $31.8 \pm 0.97{ }^{\circ} \mathrm{C}$ at summer middays. Soil moisture ranged between $2.4 \pm 0.28 \%(\mathrm{v} / \mathrm{v})$ at summer middays and $38.2 \pm 2.69 \%(\mathrm{v} / \mathrm{v})$ in winter mornings (Fig. 1). Compared to control treatment, the drought treatment 
significantly decreased soil moisture an average of $26.2 \%$ in mornings and $25.7 \%$ at midday throughout the year, with decreases ranging between $21.0 \%$ in winter mornings and $48.8 \%$ at summer middays.

\subsection{Seasonal and diurnal variation of $\mathrm{A}$ and $\mathrm{g}_{\mathrm{s}}$}

A and $\mathrm{g}_{\mathrm{s}}$ for E. multiflora seasonally varied similarly (Fig. 2A). A and $\mathrm{g}_{\mathrm{s}}$ were highest in autumn mornings, at $6.7-7.3 \mu \mathrm{mol} \mathrm{m} \mathrm{m}^{-2} \mathrm{~s}^{-1}$ and $0.079-0.090 \mathrm{~mol} \mathrm{~m}^{-2} \mathrm{~s}^{-1}$, and were lowest at winter middays, at $1.2-2.3 \mu \mathrm{mol}$ $\mathrm{m}^{-2} \mathrm{~s}^{-1}$ and $0.020-0.027 \mathrm{~mol} \mathrm{~m}^{-2} \mathrm{~s}^{-1}$, respectively. A and $\mathrm{g}_{\mathrm{s}}$ tended to be lower in the drought than the control treatments in most seasons but were significantly lower only at autumn midday for $\mathrm{A}(P<0.05)$ and summer midday for $\mathrm{g}_{\mathrm{s}}(P<0.05)$.

A and $\mathrm{g}_{\mathrm{s}}$ for $Q$. ilex were highest in spring and winter mornings (Fig. 2B), at $9.2-10.8 \mu \mathrm{mol} \mathrm{m}^{-2} \mathrm{~s}^{-1}$ and $0.208-0.215 \mathrm{~mol} \mathrm{~m}^{-2} \mathrm{~s}^{-1}$, and lowest at autumn middays at $2.8-4.7 \mu \mathrm{mol} \mathrm{m}^{-2} \mathrm{~s}^{-1}$ and $0.028-0.064 \mathrm{~mol} \mathrm{~m}^{-2} \mathrm{~s}^{-}$ ${ }^{1}$, respectively. A in the drought treatments was significantly highest in winter mornings $(P<0.05)$, and A and $\mathrm{g}_{\mathrm{s}}$ were significantly lowest in spring mornings $(P<0.05)$ and at autumn middays $(P<0.05)$, respectively.

\subsection{Seasonal and diurnal variation of isoprenoid emissions}

Isoprene was the main compound emitted by E. multiflora. The emission rates ranged between $0.40 \pm$ $0.15 \mu \mathrm{g} \mathrm{g}^{-1} \mathrm{dw} \mathrm{h}^{-1}$ at winter middays and $4.77 \pm 1.51 \mu \mathrm{g} \mathrm{g}^{-1} \mathrm{dw} \mathrm{h}^{-1}$ at summer middays (Fig. 3). The drought treatments did not affect isoprene-emission rates except for decreasing them when they were already low at winter midday $(P<0.05)$. Isoprene emission was not detected for $Q$. ilex. Both species, however, emitted volatile terpenes. $\alpha$-Pinene and limonene were the two most abundant terpenes for both species and were detected in all periods both sampling times, with trends similar to those for total terpene emission. Total terpene emissions for E. multiflora were very low, ranging between $0.10 \pm 0.05 \mu \mathrm{g} \mathrm{g}^{-1} \mathrm{dw} \mathrm{h}^{-1}$ in winter mornings and $1.05 \pm 0.32 \mu \mathrm{g} \mathrm{g}^{-1} \mathrm{dw} \mathrm{h}^{-1}$ at summer middays (Fig. 4A). Emissions did not globally differ significantly between the treatments but were lower in the drought plots at summer midday. $\alpha$-Pinene and limonene were emitted mostly at summer midday, at about 0.7 and $0.3 \mu \mathrm{g} \mathrm{g}^{-1} \mathrm{dw} \mathrm{h}^{-1}$, respectively. Q. ilex emitted terpenes at much higher rates than E. multiflora, ranging between $1.8 \pm 0.3 \mu \mathrm{g} \mathrm{g}^{-1} \mathrm{dw} \mathrm{h}^{-1}$ at winter middays and $44.1 \pm 3.2 \mu \mathrm{g} \mathrm{g}^{-1} \mathrm{dw} \mathrm{h}^{-1}$ at summer middays (Fig. 4B). Overall terpene emissions from $Q$. ilex were $19.3 \%$ higher in the morning and $35.5 \%$ higher at midday in the drought than the control treatments. Total terpene emissions from $Q$. ilex were significantly higher in the drought treatments in summer mornings $(P<0.05)$ and at summer middays $(P<0.01)$ by $39.7 \%$ and $68.0 \%$, coinciding with significantly higher $\alpha$-pinene $(P<0.05)$ and limonene $(P<0.05)$ emissions, respectively. $\alpha$-Pinene and limonene were emitted mostly at summer middays, at rates of about $13 \mu \mathrm{g} \mathrm{g}^{-1} \mathrm{dw} \mathrm{h}^{-1}$ for both.

\section{Discussion}

Plants in Mediterranean-type climates have similar physiological trends, with A and $\mathrm{g}_{\mathrm{s}}$ highest in spring or autumn when environmental conditions are favorable (Llusià et al., 2013; Liu et al., 2016). A and $\mathrm{g}_{\mathrm{s}}$ for Q. ilex in our study were highest in winter, probably due to the extremely uneven distribution of water availability in 2013-2014 (Fig. 1). A and $\mathrm{g}_{\mathrm{s}}$ tended to decrease from winter to summer with increasing heat and drought (Fig. 2B). Plants generally accumulate carbon under moderate drought stress due to growth 
restriction by water deficiency but may temporarily decrease photosynthetic activity when water stress is severe because of the increased resistance to $\mathrm{CO}_{2}$ in both the stomata and mesophyll (Centritto et al., 2003; Ogaya and Peñuelas, 2003; Llusià et al., 2006). These low rates of photosynthesis and stomatal conductance indicate that plants can successfully adapt to severe stress caused by extreme climatic environments by slowing growth and reproduction (Llusià et al., 2013; Matesanz and Valladares 2014; Bussotti et al., 2015).

The emission of isoprenoids differed between the species (Llusià and Peñuelas, 2000; Peñuelas and Llusià, 2001) but followed a similar seasonal pattern (Figs. 3, 4A and B). The seasonal pattern agreed with previous results of isoprenoid emissions in most Mediterranean species, with a maximum in summer and a minimum in cold seasons (Llusià and Peñuelas, 2000; Llusià et al., 2011). The seasonality is due to the dependence of metabolic regulation on many abiotic factors, but temperature is likely the dominant driver of emission (Llusià and Peñuelas, 2000).

Isoprenoid-emission rates for E. multiflora were inside the range of $0.5-20 \mu \mathrm{g} \mathrm{g}^{-1} \mathrm{dw} \mathrm{h}^{-1}$ reported by Owen et al. (1997) and also inside the ranges for isoprene emissions of 0.15-4.4 $\mu \mathrm{g} \mathrm{g}^{-1} \mathrm{dw} \mathrm{h}^{-1}$ and monoterpene emissions of 0.08-0.4 $\mu \mathrm{g} \mathrm{g}^{-1} \mathrm{dw} \mathrm{h}^{-1}$ reported by Llusià et al. (2009). 2014 was a relatively wet and warm year for Garraf (Fig. 1). The drought treatment decreased soil moisture by only about $5 \%$, and emissions were similar in all seasons except summer (Figs. 3 and 4A). The differences of emission rates between treatments may have been due to a combination of factors dominated by temperature variation. The small differences in soil moisture caused little change in plant physiology and did not substantially influence emission rates on a yearly scale.

Q. ilex is a non-stored species with strong emission capacity of terpenes, especially in hot seasons, and is highly sensitive to drought (Llusià and Peñuelas, 2000; Loreto et al., 2001; Llusià et al., 2011; Llusià et al., 2013). Heat and water distribution were extremely unbalanced in Prades (Fig. 1). Terpene-emission rates for Q. ilex were higher than previously reported (Llusià et al., 2011), especially for the temperate seasons due to the warmer and drier environmental conditions, but the drought treatment had no significant effects, probably because the treatment was not severe enough for $Q$. ilex to adjust emissions for adapting to drought. The plants were able to maintain a stable status after a long acclimation to a moderate drought in these seasons (Fig. 4B). Terpene emissions from $Q$. ilex, however, were significantly higher only in summer in the drought treatment. An increase in emission in response to moderate drought has also been reported in other studies (Llusià et al., 2006; Llusià et al., 2011) and supports the existence of an interaction between drought and high temperature (Blanch et al., 2009). The increase in terpene emissions under drought conditions may be also attributed to a combination of other factors such as high radiation and temperature (Osmond et al., 1997; Llusià et al., 2006) for avoiding damage to cellular membranes caused by oxygenated products generated under summer stressful environmental conditions (Gershenzon et al., 1978; Peñuelas and Llusià, 2001; Loreto et al., 2001).

The monoterpenes $\alpha$-pinene and limonene were the main terpenes emitted by the two species. Their emission trends were similar to those for total terpenes, with a maximum in summer and a minimum in winter (Fig. 4A and B). $\alpha$-Pinene and limonene emissions from E. multiflora were low and lower in the drought treatments than in control treatments at summer midday (Fig. 4A). $\alpha$-Pinene emission from Q. ilex was highly sensitive to temperature, increasing sharply from winter to spring (Fig. 4B), and the emission rates even increased $(P<0.05)$ with air temperature in the control treatment in spring mornings (Figs. 1 
and 4B), indicating that temperature was a more powerful driving force than moderate drought on $\alpha$-pinene emissions. Limonene emission responded strongly to water deficiency, most obviously at the driest summer midday $(P<0.001)$, coinciding with a significantly higher emission $(P<0.01)$ (Fig. 4B). The increased emissions of the two main terpenes in response to temperature and moderate drought has also been found in other studies (Bertin and Staudt, 1996; Llusià et al., 2011). Not all terpene emissions, however, were higher in the drought treatment in summer. The various responses may have been due to the activities of synthases and to the potential protective roles of the various terpenes under drought conditions (Blanch et al., 2009).

Photosynthetic rates and stomatal conductance were higher in both species in the morning than at midday for most seasons, but isoprenoid emissions had the opposite trends (Fig. 2A and B). A and $\mathrm{g}_{\mathrm{s}}(P<0.01)$ and isoprene emissions $(P<0.05)$ for E. multiflora differed significantly between the two diurnal periods, and drought treatments in spring to autumn days decreased photosynthetic rates and stomatal conductance $(P<0.05)$ more at midday (Fig. 2A). These two opposite trends identified an important aspect of photosynthetic carbon fixation at midday that is still used for having a larger terpene production than in the morning (Peñuelas and Llusià 1999; Vallat et al., 2005; Blanch et al., 2009), and emissions in the drought treatment were much higher at summer midday (Figs. 3, 4A and B). However, isoprenoid emissions from plants generally do not only depend on the current environmental drivers, but also the preceding environmental and physiological status (Llusià et al., 2013; Tiiva et al., 2017) which may also suggest a high emission potential at more severe midday conditions if there is high A in morning (Fig. 2, 3 and 4). The higher percentages of fixed carbon devoted to terpene emission at midday also indicate a successful adaptation of plants by adjusting metabolism under environmental stress (Litvak et al., 1996; Loreto et al., 2001).

Environmental conditions such as air temperature and soil moisture are the main factors that determine plant physiological responses, including BVOC emissions (Llusià et al., 2006, 2009 and 2011; Peñuelas and Llusià, 2001; Filella, et al., 2007; Blanch et al., 2009). We analyzed the corresponding correlations and generalized them with linear or exponential algorithms (Table 1). The emission rates of the main isoprenoids were correlated positively with air temperature and negatively with soil moisture for both species (Fig. 5). The relationships with environmental conditions were stronger for $Q$. ilex than E. multiflora. The production of isoprenoids has been linked to an increased tolerance to water stress in some species (Peñuelas and Llusià, 2001; Blanch et al., 2009), and plants under severe drought conditions may even decrease their emissions (Llusià and Peñuelas, 2000). These results indicate that higher isoprenoid emissions can be expected in the warmer and drier conditions projected by climatic and ecophysiological models for the coming decades in the Mediterranean region (Peñuelas and Llusià, 2001; IPCC, 2014). The most widely used Model of Emissions of Gasses and Aerosols from Nature (MEGAN) model (Guenther et al., 2012) initially estimated the emissions depending on species-specific capacities of foliar emissions, light and temperature (Bertin and Staudt, 1996; Guenther et al., 2012; Llusià et al., 2013). In its latest version, MEGAN2.1 (Guenther et al., 2012) has included a simple drought algorithm for isoprene emissions derived from the observations of Pegoraro et al. (2004). This improvement of the model MEGAN could still not describe the actual emission rates in response to drought since that algorithm only predicts reduction in emissions (Guenther et al., 2012) and not possible increases at mild drought conditions. It cannot, 
moreover, account properly for the seasonal variation of the enzymatic activity regulating the basal emission factor (BEF) employed in the model (Schnitzler et al. 1996; Brilli et al., 2016). Neglecting seasonal drought stress could lead to large misestimates of drought influences on isoprenoid emissions. Failing to fully take into consideration the capacity of plants to acclimate, which varies widely among seasons and even within a season if the environment changes, may also lead to misestimates. Although previous studies have shown that terpenes, especially for monoterpenes and sesquiterpenes, are to a large extent emitted in a manner similar to that of isoprene depending on both temperature and light (Sindelarova et al. 2014), an improvement of current models is also required to better predict the dynamics of both basal and total isoprenoid emissions, especially under the increasing intensity of drought stress (Filella et al., 2018; IPCC, 2014). The trends of isoprenoid emissions are very important due to their potential roles in plant flammability (Alessio et al., 2008; Llusià et al., 2011) and atmospheric chemical processes contributing to ozone formation and even affecting climate (Thompson, 1992; Peñuelas and Llusià, 2003; Dicke and Loreto, 2010; Seco et al., 2013).

\section{Acknowledgements}

This research was financially supported by the Spanish Government project CGL2016-79835-P, the Catalan government project SGR2014-274, and the ERC Synergy project SyG-2013-610028 IMBALANCE-P. We are also grateful for the financial support from the China Scholarship Council.

\section{Figure captions}

Fig. 1. Seasonal morning and midday time-courses of mean air temperature and soil moisture in Garraf and Prades. Error bars indicate standard errors of the means; $\mathrm{n}=6\left({ }^{*} \mathrm{P}<0.05,{ }^{*} \mathrm{P}<0.01\right.$ and $* * * \mathrm{P}<0.001$ indicate significant differences between treatments identified by Student's t-tests). The significances of the effects of season, treatment and sampling time (repeated measurements ANOVA) are depicted in each panel.

Fig. 2. Seasonal net photosynthetic rates and stomatal conductances for E. multiflora (A) and Q. ilex (B) in the morning and at midday. Error bars indicate standard errors of the means; $n=9$ (* $P<0.05$ indicates significant differences between treatments identified by Student's $t$-tests). The significances of the effects of season, treatment and sampling time (repeated measurements ANOVA) are depicted in each panel.

Fig. 3. Seasonal time courses of the rate of isoprene emission for E. multiflora. Error bars indicate standard errors of the means; $n=6{ }^{*} P<0.05$ indicates significant differences between treatments identified by Student's $t$-tests). The effects of season, treatment and sampling time are depicted in the panels when significant.

Fig. 4. Seasonal time courses for the rates of emission of total terpenes, $\alpha$-pinene and limonene for $E$. multiflora (A) and Q. ilex (B). Error bars indicate standard errors of the means; $n=6$ ( $^{*} P<0.05$ and ** $\mathrm{P}$ $<0.01$ indicate significant differences between treatments identified by Student's $t$-tests). The effects of season, treatment and sampling time are depicted in the panels when significant.

Fig. 5. Relationships for the emissions of the main isoprenoids with air temperature and soil moisture for E. multiflora and $Q$. ilex. 


\section{Table caption}

Table 1. Relationships for the emissions of the main isoprenoids (isoprene for E. multiflora and total terpenes for $Q$. ilex) with air temperature and soil moisture (SE, standard error).

\section{References}

Alessio, G.A., Peñuelas, J., Llusià, J., Ogaya, R., Estiarte, M., De Lillis, M., 2008. Influence of water and terpenes on flammability in some dominant Mediterranean species. Int. J. Wildl. Fire 17, 274-286.

Alexieva, V., Sergiev, I., Mapelli, S., Karanov, E., 2001. The effect of drought and ultraviolet radiation on growth and stress markers in pea and wheat. Plant, Cell Environ. 24, 1337-1344.

Bai, J., Xu, D.H., Kang, H.M., Chen, K., Wang, G., 2008. Photoprotective function of photorespiration in Reaumuria soongorica during different levels of drought stress in natural high irradiance. Photosynthetica 46, 232-237.

Beier, C., Beierkuhnlein, C., Wohlgemuth, T., Peñuelas, J., Emmett, B., Körner, C., De Boeck, H., Christensen, J.H., Leuzinger, S., Janssens, I.A., Hansen, K., 2012. Precipitation manipulation experiments - challenges and recommendations for the future. Ecol. Lett. 15, 899-911.

Bertin, N., Staudt, M., 1996. Effect of water stress on monoterpene emission from young potted holm oak (Quercus ilex L.) trees. Oecologia. 107, 456-462.

Blanch, J.S., Peñuelas, J., Sardans, J., Llusià, J., 2009. Drought, warming and soil fertilization effects on leaf volatile terpene concentrations in Pinus halepensis and Quercus ilex. Acta Physiol. Plant. 31, 207-218.

Bolòs, O., Vigo, J., 1990. Flora dels Països Catalans. Barcino Press, Barcelona.

Brilli, F., Gioli, B., Fares, S., Terenzio, Z., Zona, D., Gielen, B., Loreto, F., A.Janssens, I., Ceulemans, R., 2016. Rapid leaf development drives the seasonal pattern of volatile organic compound (VOC) fluxes in a "coppiced" bioenergy poplar plantation. Plant, Cell Environ. 39, 539-555.

Bussotti, F., Pollastrini, M., Holland, V., Brüggemann, W., 2015. Functional traits and adaptive capacity of European forests to climate change. Environ. Exp. Bot. 111, 91-113.

Carslaw, K.S., Boucher, O., Spracklen, D. V., Mann, G.W., Rae, J.G.L., Woodward, S., Kulmala, M., 2009. Atmospheric aerosols in the earth system: a review of interactions and feedbacks. Atmos. Chem. Phys. Discuss. 9, 11087-11183.

Centritto, M., Loreto, F., Chartzoulakis, K., 2003. The use of low $\left[\mathrm{CO}_{2}\right]$ to estimate diffusional and nondiffusional limitations of photosynthetic capacity of salt-stressed olive saplings. Plant, Cell Environ. 26, 585-594.

Chaves, M.M., Pereira, J.S., Maroco, J., Rodrigues, M.L., Ricardo, C.P., Osorio, M.L., Carvalho, I., Faria, T., Pinheiro, C., 2002. How plants cope with water stress in the field. Photosynthesis and growth. Ann. Bot. 89, 907-916.

Claeys, M., Graham, B., Vas, G., Wang, W., Vermeylen, R., Pashynaka, V., Cafmeyer, J., Guyon, P., Andreae, M.O., Artaxo P., Maenhaut, W., 2004. Formation of Secondary Organic Aerosols Through Photooxidation of Isoprene. Science 303, 1173-1176.

Copolovici, L.O., Filella, I., Llusià, J., Niinemets, Ü., Peñuelas, J., 2005. The Capacity for Thermal 
Protection of Photosynthetic Electron Transport Varies for Different Monoterpenes in Quercus ilex. Plant Physiol. 139, 485-496.

Daie, J., Patrick, J.W., 1988. Mechanism of drought induced alteration in assimilate partitioning and transport in crops. Critical Reviews in Plant Science 7, 117-137.

De Boeck, H.J., Vicca, S., Roy, J., Nijs, I., Milcu, A., Kreyling, J., Jentsch, A., Chabbi, A., Campioli, M., Callaghan, T., Beierkuhnlein, C., Beier, C., 2015. Global Change Experiments: Challenges and Opportunities. Bioscience 65, 922-931.

Di Carlo, P., Brune, W.H., Martinez, M., Harder, H., Lesher, R., Ren, X., Campbell, C., 2004. Missing OH reactivity in a forest: evidence for unknown reactive biogenic VOCs. Science 304, 722-725.

Dicke, M., Loreto, F., 2010. Induced plant volatiles: from genes to climate change. Trends Plant Sci. 15, $115-117$.

Dobrota, C., 2006. Energy dependant plant stress acclimation. Life Extrem. Environ. 277-285. Filella, I., Wilkinson, M.J., Llusià, J., Hewitt, C.N., Peñuelas, J., 2007. Volatile organic compounds emissions in Norway spruce (Picea abies) in response to temperature changes. Physiol. Plant. 130, 58-66.

Filella, I., Zhang, C., Seco, R., Potosnak, M., Guenther, A., Karl, T., Gamon, J., Pallardy, S., Gu, L., Kim, S., Balzarolo, M., Fernandez-Martinez, M., Penuelas, J., 2018. A MODIS Photochemical Reflectance Index (PRI) as an Estimator of Isoprene Emissions in a Temperate Deciduous Forest. . Remote Sens. $10,557$.

Gershenzon, J., Lincoln, D.E., Langenheim, J.H., 1978. Effect of Moisture Stress on Monoterpenoid Yield and Composition in Satureja-Douglasii. Biochem. Syst. Ecol. 6, 33-43.

Guenther, A., 1997. Seasonal and spatial variations in natural volatile organic compound emissions. Ecol. Appl. 7, 34-45.

Guenther, A.B., Jiang,X., Heald, C.L., Sakulyanontvittaya, T., Duhl, T., Emmons, L.K., Wang, X., 2012. The Model of Emissions of Gases and Aerosols from Nature version 2.1 (MEGAN2.1): an extended and updated framework for modeling biogenic emissions. Geosci. Model Dev. 5, 1471-1492,

Hansen, U., Seufert, G., 1999. Terpenoid emission from Citrus sinensis (L.) OSBECK under drought stress. Phys. Chem. Earth, Part B Hydrol. Ocean. Atmos. 24, 681-687.

Holopainen, J.K., Gershenzon, J., 2010. Multiple stress factors and the emission of plant VOCs. Trends Plant Sci. 15, 176-184.

Hsiao, T.C., 1973. Plant responses to water stress. Ann. Rev. Plant Physiol. 24, 519-570.

IPCC, 2007. The scientific basis. (Contribution of working group I to the Fourth assessment report of the intergovernmental panel on climate change). Cambridge University Press, New York.

IPCC, 2014. Part A: Global and Sectoral Aspects. (Contribution of Working Group II to the Fifth Assessment Report of the Intergovernmental Panel on Climate Change). Cambridge University Press, New York.

Kreuzwieser, J., Schnitzler, J.P., Steinbrecher, R., 1999 Biosynthesis of organic compounds emitted by plants. Plant Biol. 2, 149-159.

Kroll, J.H., Seinfeld, J.H., 2008. Chemistry of secondary organic aerosol: Formation and evolution of lowvolatility organics in the atmosphere. Atmos. Environ. 42, 3593-3624.

Laothawornkitkul, J., Taylor, J.E., Paul, N.D., Hewitt, C.N., 2009. Biogenic volatile organic compounds in 
the Earth system: Tansley review. New Phytol. 183, 27-51.

Lerdau, M., Guenther, A., Monson, R., 1997. Plant production and emission of volatile organic compounds. Bioscience 47, 373-383.

Leuzinger, S., Luo, Y., Beier, C., Dieleman, W., Vicca, S., Körner, C., 2011. Do global change experiments overestimate impacts on terrestrial ecosystems? Trends Ecol. Evol. 26, 236-241.

Limousin, J.M., Misson, L., Lavoir, A.V., Martin, N.K., Rambal, S., 2010. Do photosynthetic limitations of evergreen Quercus ilex leaves change with long-term increased drought severity? Plant, Cell Environ. 33, 863-875.

Litvak, M.E., Loreto, F., Harley, P.C., Sharkey, T.D., Monson, R.K., 1996. The response of isoprene emission rate and photosynthetic rate to photon flux and nitrogen supply in aspen and white oak trees. Plant, Cell Environ. 19, 549-559.

Liu, D., Llusià, J., Ogaya, R., Estiarte, M., Llorens, L., Yang, X., Peñuelas, J., 2016. Physiological adjustments of a Mediterranean shrub to long-term experimental warming and drought treatments. Plant Sci. 252, 53-61.

Llusià, J., Bermejo-Bermejo, V., Calvete-Sogo, H., Peñuelas, J., 2014. Decreased rates of terpene emissions in Ornithopus compressus L. and Trifolium striatum L. by ozone exposure and nitrogen fertilization. Environ. Pollut. 194, 69-77.

Llusià, J., Peñuelas, J., 2000. Seasonal patterns of terpene content and emission from seven Mediterranean woody species in field conditions. Am. J. Bot. 87, 133-140.

Llusià, J., Peñuelas, J., Alessio, G.A., Estiarte, M., 2006. Seasonal contrasting changes of foliar concentrations of terpenes and other volatile organic compound in four dominant species of a Mediterranean shrubland submitted to a field experimental drought and warming. Physiol. Plant. 127, 632-649.

Llusià, J., Peñuelas, J., Alessio, G.A., Ogaya, R., 2011. Species-specific, seasonal, inter-annual, and historically-accumulated changes in foliar terpene emission rates in Phillyrea latifolia and Quercus ilex submitted to rain exclusion in the Prades Mountains (Catalonia). Russ. J. Plant Physiol. 58, 126132.

Llusià, J., Peñuelas, J., Guenther, A., Rapparini, F., 2013. Seasonal variations in terpene emission factors of dominant species in four ecosystems in NE Spain. Atmos. Environ. 70, 149-158.

Llusià, J., Peñuelas, J.,Prieto, P., Estiarte M., 2009. Net ecosystem exchange and whole plant isoprenoid emissions by a Mediterranean shrubland exposed to experimental climate change. Russ. J. Plant Physiol. 56, 29-37.

Loreto, F., Fischbach, R.J., Schnitzler, J.P., Ciccioli, P., Brancaleoni, E., Calfapietra, C., Seufert, G., 2001. Monoterpene emission and monoterpene synthase activities in the Mediterranean evergreen oak Quercus ilex L. grown at elevated $\mathrm{CO}_{2}$ concentrations. Glob. Chang. Biol. 7, 709-717.

Loreto, F., Schnitzler, J.P., 2010. Abiotic stresses and induced BVOCs. Trends Plant Sci. 15, 154-166.

Matesanz, S., Valladares, F., 2014. Ecological and evolutionary responses of Mediterranean plants to global change. Environ. Exp. Bot. 103, 53-67.

Niederbacher, B., Winkler, J.B., Schnitzler, J.P., 2015. Volatile organic compounds as non-invasive markers for plant phenotyping. J. Exp. Bot. 66, 5403-5416. 
Ogaya, R., Llusià, J., Barbeta, A., Asensio, D., Liu, D., Alessio, G.A., Peñuelas, J., 2014. Foliar $\mathrm{CO}_{2}$ in a holm oak forest subjected to 15 years of climate change simulation. Plant Sci. 226, 101-107.

Ogaya, R.., Peñuelas, J., 2003. Comparative seasonal gas exchange and chorophyll fluorescence of two dominant woody species in a Holm Oak Forest. Flora 198, 132-141.

Osmond, B., Badger, M., Maxwell, K., Bjorkman, O., Leegod, R., 1997. Too many photons: photorespiration, photoinhibition and photooxidation. Trends Plant Sci. 2, 119-120.

Owen, S., Boissard, C., Street, R.A., Duckham, S.C., Csiky, O., Hewitt, C.N., 1997. Screening of 18 Mediterranean plant species for volatile organic compound emissions. Atmos. Environ. 31, 101-117.

Paris, C.I., Llusià, J., Peñuelas, J., 2010. Changes in monoterpene emission rates of Quercus ilex infested by aphids tended by native or invasive lasius ant species. J. Chem. Ecol. 36, 689-698.

Pegoraro, E., Rey, A., Greenberg, J., Harley, P., Grace, J., Malhi, Y., Guenther, A., 2004. Effect of drought on isoprene emission rates from leaves of Quercus virginiana Mill. Atmos. Environ. 38, 6149-6156.

Peñuelas, J., Boada, M., 2003. A global change-induced biome shift in the Montseny mountains (NE Spain). Glob. Chang. Biol. 9, 131-140.

Peñuelas, J., Llusià, J., 1999. Seasonal emission of monoterpenes by the Mediterranean tree Quercus ilex in field conditions: relations with photosynthetic rates, temperature and volatility. Physiol. Plant. 105, 641-647.

Peñuelas, J., Llusià, J., 2001. The complexity of factors driving volatile organic compound emissions. Biol. Plant. 44, 481-487.

Peñuelas, J., Llusià, J., 2003. BVOCs: Plant defense against climate warming? Trends Plant Sci. 8, 105109.

Peñuelas, J., Munné-Bosch, S., 2005. Isoprenoids: An evolutionary pool for photoprotection. Trends Plant Sci. 10, 166-169.

Peñuelas, J., Sardans, J., Estiarte, M., Ogaya, R., Carnicer, J., Coll, M., Barbeta, A., Rivas-Ubach, A., Llusià, J., Garbulsky, M., Filella, I., Jump, A.S., 2013. Evidence of current impact of climate change on life: A walk from genes to the biosphere. Glob. Chang. Biol. 19, 2303-2338.

Piñol, J., Terradas, J., Lloret, F., 1998. Climate warming, wildfire hazard, and wilfire occurence in coastal eastern Spain. Int. J. Wildl. fire 11, 95-106.

Porcar-Castell, A., Peñuelas, J., Owen, S.M., Llusià, J., Munné-Bosch, S., Bäck, J., 2009. Leaf carotenoid concentrations and monoterpene emission capacity under acclimation of the light reactions of photosynthesis. Boreal Environ. Res. 14, 794-806.

Prieto, P., Peñuelas, J., Llusià, J., Asensio, D., Estiarte, M., 2009. Effects of long-term experimental nighttime warming and drought on photosynthesis, Fv/Fm and stomatal conductance in the dominant species of a Mediterranean shrubland. Acta Physiol. Plant. 31, 729-739.

Rennenberg, H., Loreto, F., Polle, A., Brilli, F., Fares, S., Beniwal, R.S., Gessler, A., 2006. Physiological responses of forest trees to heat and drought. Plant Biol. 8, 556-571.

Riipinen, I., Yli-Juuti, T., Pierce, J.R., Petäjä, T., Worsnop, D.R., Kulmala, M., Donahue, N.M., 2012. The contribution of organics to atmospheric nanoparticle growth. Nat. Geosci. 5, 453-458.

Rubio-Casal, A.E., Leira-Doce, P., Figueroa, M.E., Castillo, J.M., 2010. Contrasted tolerance to low and high temperatures of three tree taxa co-occurring on coastal dune forests under Mediterranean climate. 
J. Arid Environ. 74, 429-439.

Sabaté, S., Gracia, C.A., Sánchez, A., 2002. Likely effects of climate change on growth of Quercus ilex,

Pinus halepensis, Pinus pinaster, Pinus sylvestris and Fagus sylvatica forests in the Mediterranean region. For. Ecol. Manage. 162, 23-37.

Sardans, J., Peñuelas, J., 2007. Drought changes phosphorus and potassium accumulation patterns in an evergreen Mediterranean forest. Funct. Ecol. 21, 191-201.

Schnitzler, J.P., Lehning, A., Steinbrecher, R., 1996. Seasonal pattern of isoprene synthase activity in Quercus robur leaves and its significance for modelling isoprene emission rates. Botanica. Acta. 110, 240-243.

Seco, R., Peñuelas, J., Filella, I., Llusià, J., Schallhart, S., Metzger, A., Müller, M., Hansel, A., 2013. Volatile organic compounds in the western Mediterranean basin: Urban and rural winter measurements during the DAURE campaign. Atmos. Chem. Phys. 13, 4291-4306.

Seddon, A.W.R., Macias-Fauria, M., Long, P.R., Benz, D., Willis, K.J., 2016. Sensitivity of global terrestrial ecosystems to climate variability. Nature 531, 229-232.

Sindelarova, K., Granier, C., Bouarar, I., Guenther, A., Tilmes, S., Stavrakou, T., Müller, J.-F., Kuhn, U., Stefani, P., Knorr, W., 2014. Global data set of biogenic VOC emissions calculated by the MEGAN model over the last 30 years. Atmos. Chem. Phys. 14, 9317-9341.

Staudt, M., Seufert, G., 1995. Light-dependent emission of monoterpenes by holm oak (Quercus ilex L.). Naturwissenschaften 82, 89-92.

Tiiva, P., Tang, J., Michelsen, A., \& Rinnan, R. (2017). Monoterpene emissions in response to long-term night-time warming, elevated $\mathrm{CO}_{2}$ and extended summer drought in a temperate heath ecosystem. Science of the Total Environment, 580, 1056-1067.

Thompson, A.M., 1992. The oxidizing capacity of the Earth's atmosphere: probable past and future changes. Science 256, 1157-1165.

Tsakiris, G., Pangalou, D., Vangelis, H., 2007. Regional drought assessment based on the Reconnaissance Drought Index (RDI). Water Resour. Manag. 21, 821-833.

Vallat, A., Gu, H., Dorn, S., 2005. How rainfall, relative humidity and temperature influence volatile emissions from apple trees in situ. Phytochemistry 66, 1540-1550.

Valolahti, H., Kivimäenpää, M., Faubert, P., Michelsen, A., Rinnan, R., 2015. Climate change-induced vegetation change as a driver of increased subarctic biogenic volatile organic compound emissions. Glob. Chang. Biol. 21, 3478-3488.

Velikova, V., Pinelli, P., Pasqualini, S., Reale, L., Ferranti, F., Loreto, F., 2005. Isoprene decreases the concentration of nitric oxide in leaves exposed to elevated ozone. New Phytol. 166, 419-425.

Yuan, J.S., Himanen, S.J., Holopainen, J.K., Chen, F., Stewart, C.N., 2009. Smelling global climate change: mitigation of function for plant volatile organic compounds. Trends Ecol. Evol. 24, 323-331. 

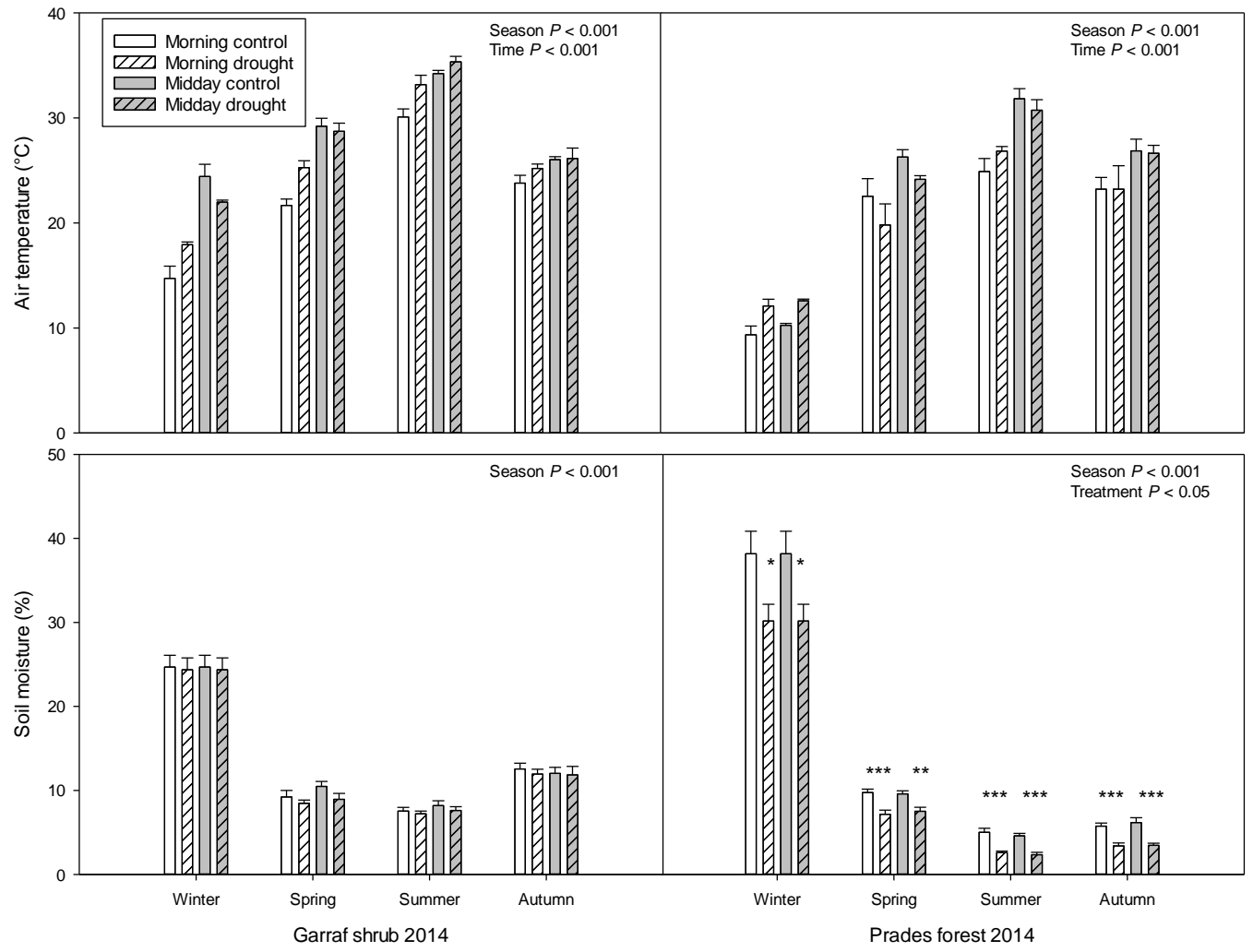

Fig. 1. Seasonal morning and midday time-courses of mean air temperature and soil moisture in Garraf and Prades. Error bars indicate standard errors of the means; $n=6(* \mathrm{P}<0.05$, ** $\mathrm{P}<0.01$ and $* * * \mathrm{P}<0.001$ indicate significant differences between treatments identified by Student's t-tests). The significances of the effects of season, treatment and sampling time (repeated measurements ANOVA) are depicted in each panel. 
A)

Erica multiflora

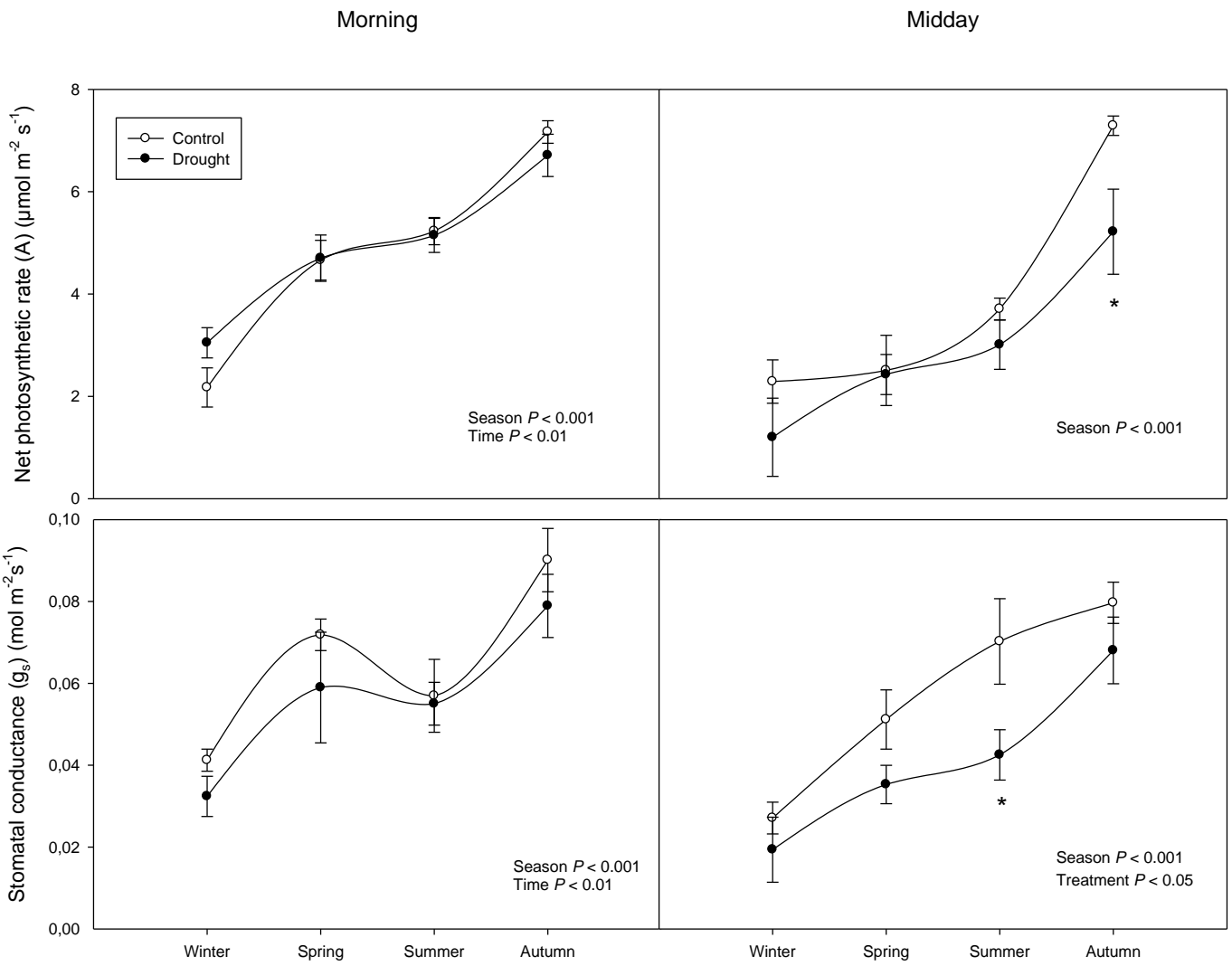

B) 


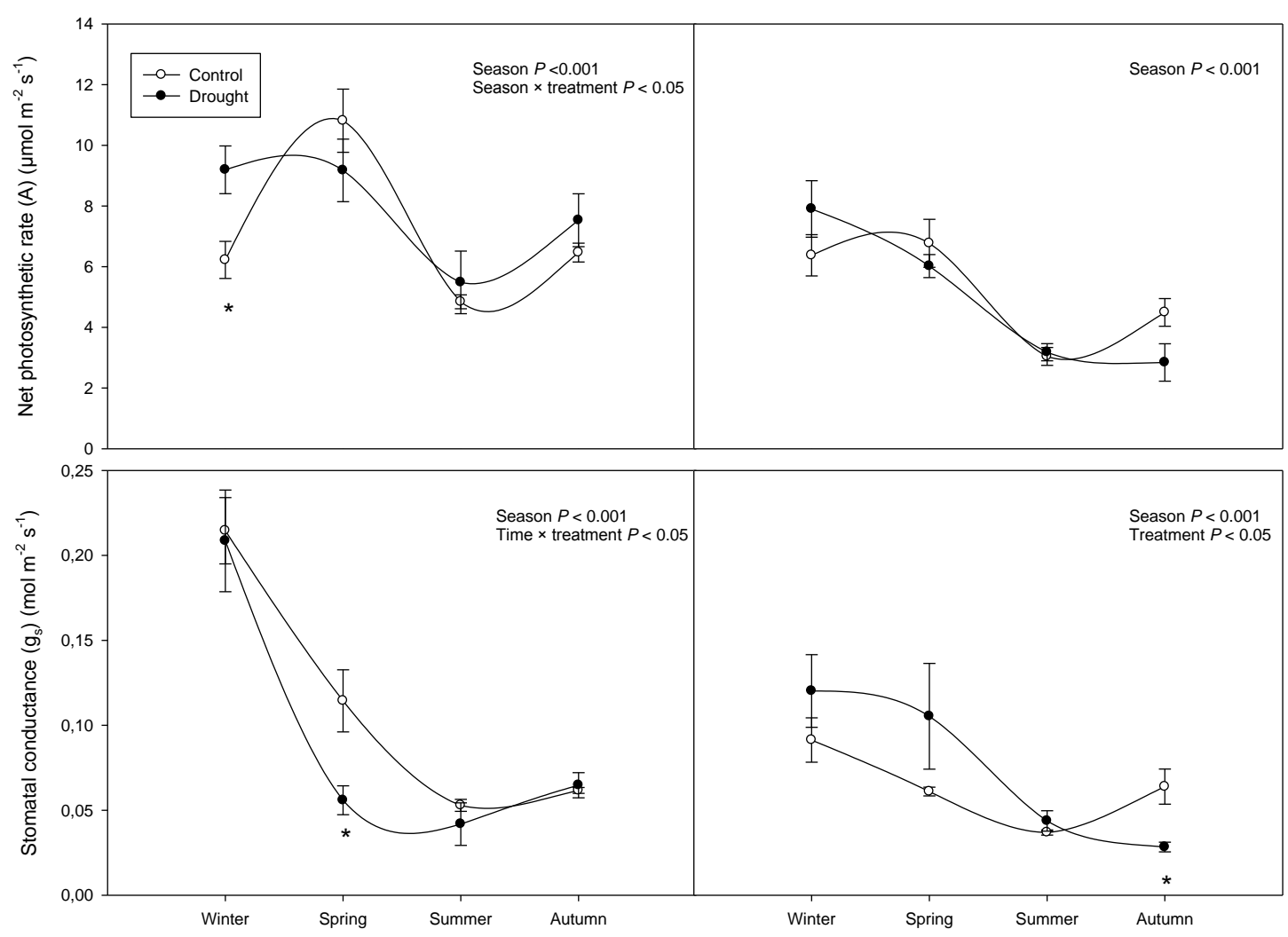

Fig. 2. Seasonal net photosynthetic rates and stomatal conductances for E. multiflora (A) and Q. ilex (B) in the morning and at midday. Error bars indicate standard errors of the means; $n=9$ ( $^{*} P<0.05$ indicates significant differences between treatments identified by Student's $t$-tests). The significances of the effects of season, treatment and sampling time (repeated measurements ANOVA) are depicted in each panel. 


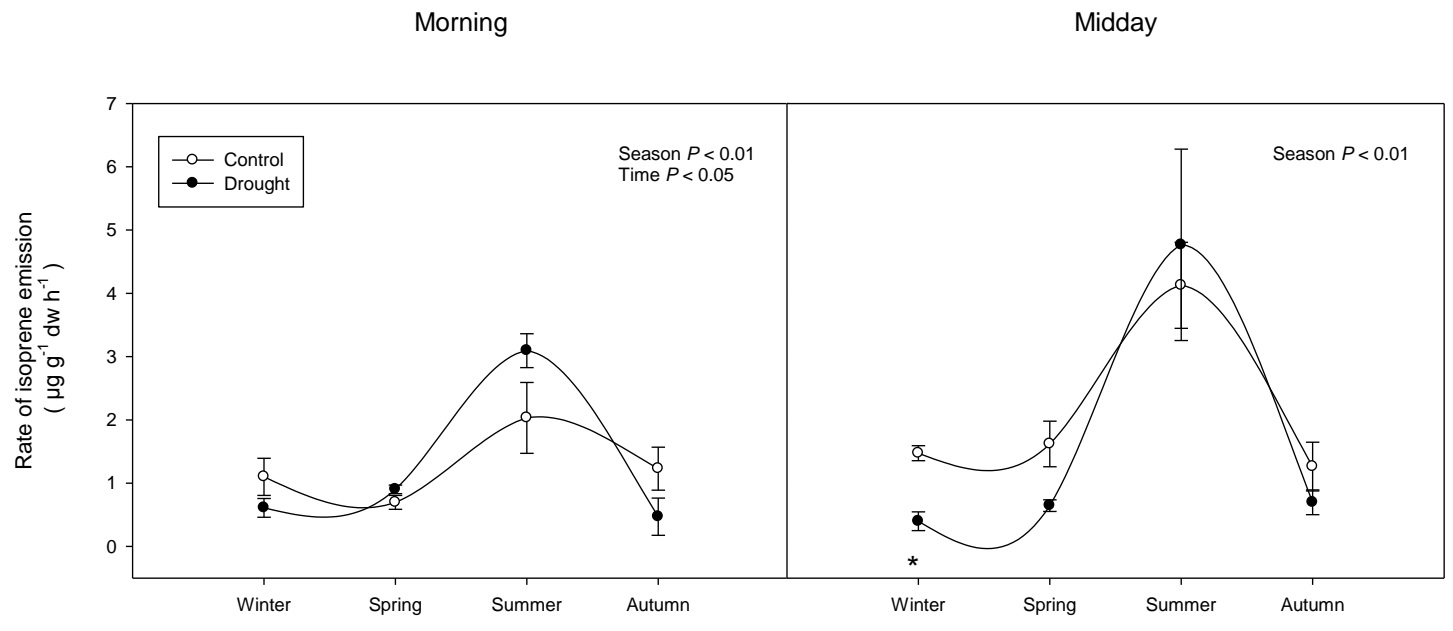

Fig. 3. Seasonal time courses of the rate of isoprene emission for E. multiflora. Error bars indicate standard errors of the means; $n=6$ (* $P<0.05$ indicates significant differences between treatments identified by Student's $t$-tests). The effects of season, treatment and sampling time are depicted in the panels when significant. 
A)

Erica multiflora

Morning

Midday
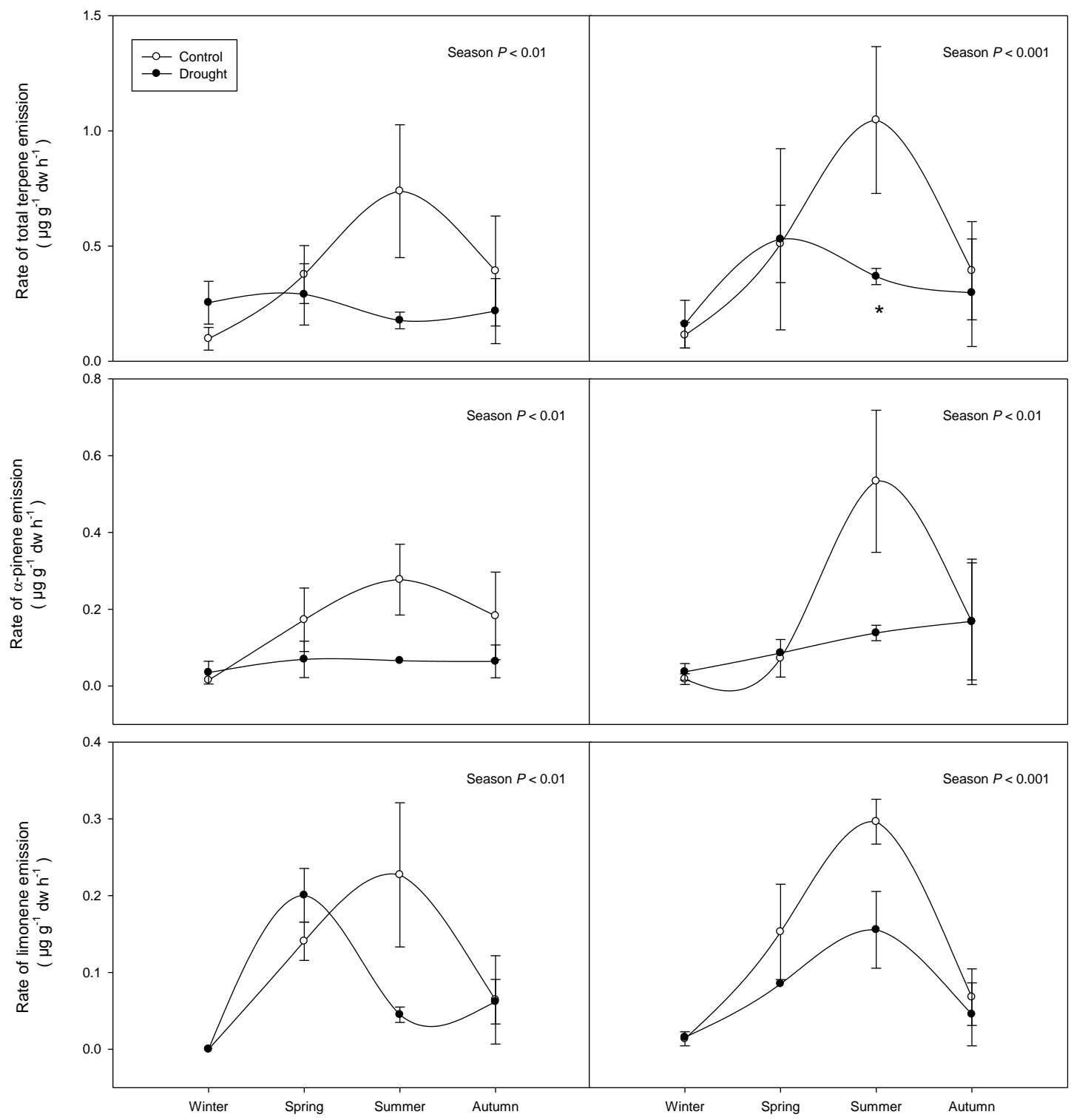
B)

Quercus ilex

Morning

Midday
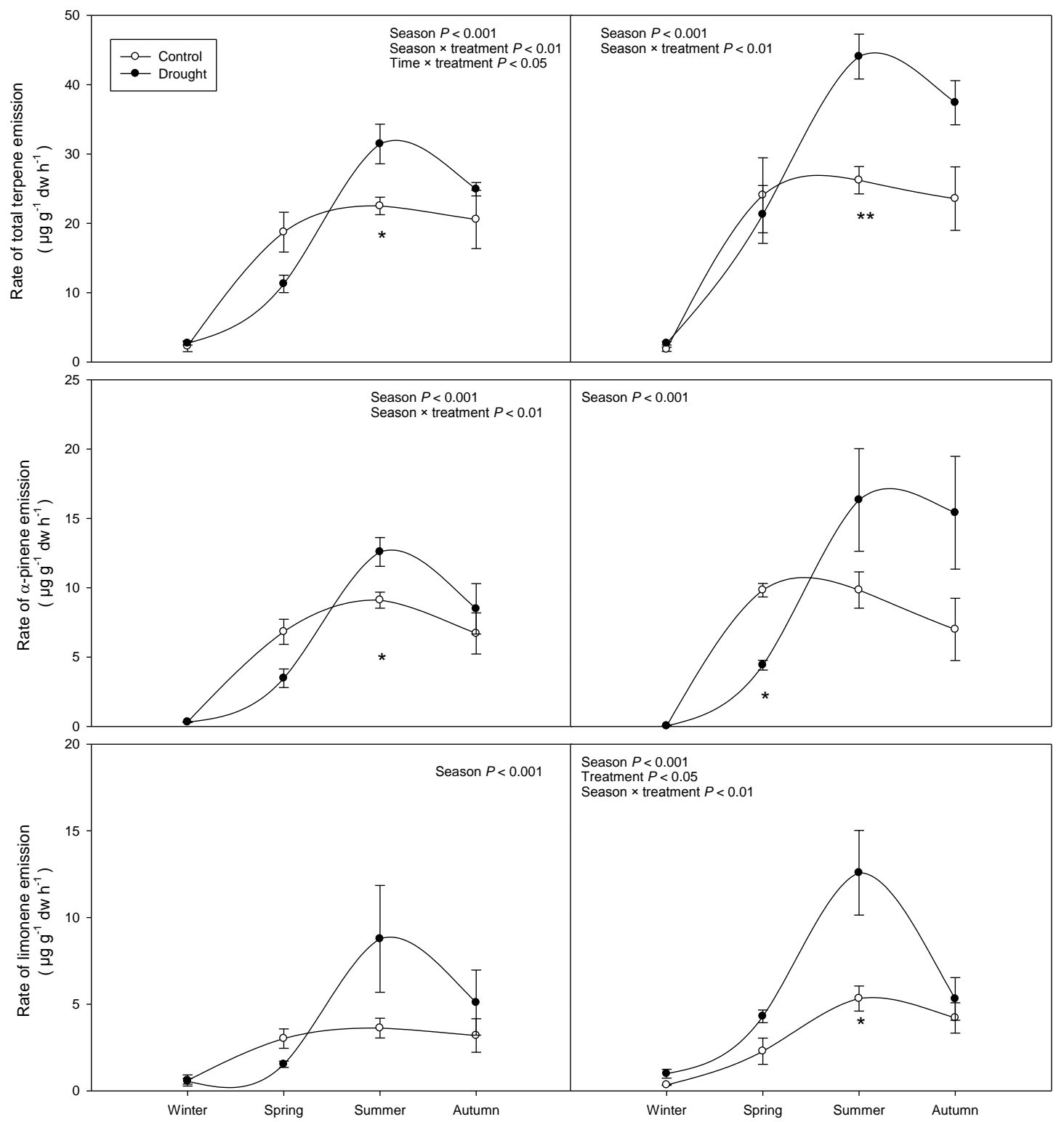

Fig. 4. Seasonal time courses for the rates of emission of total terpenes, $\alpha$-pinene and limonene for E. multiflora (A) and $Q$. ilex (B). Error bars indicate standard errors of the means; $n=6(* P<0.05$ and $* * P<0.01$ indicate significant differences between treatments identified by Student's $t$-tests). The effects of season, treatment and sampling time are depicted in the panels when significant. 

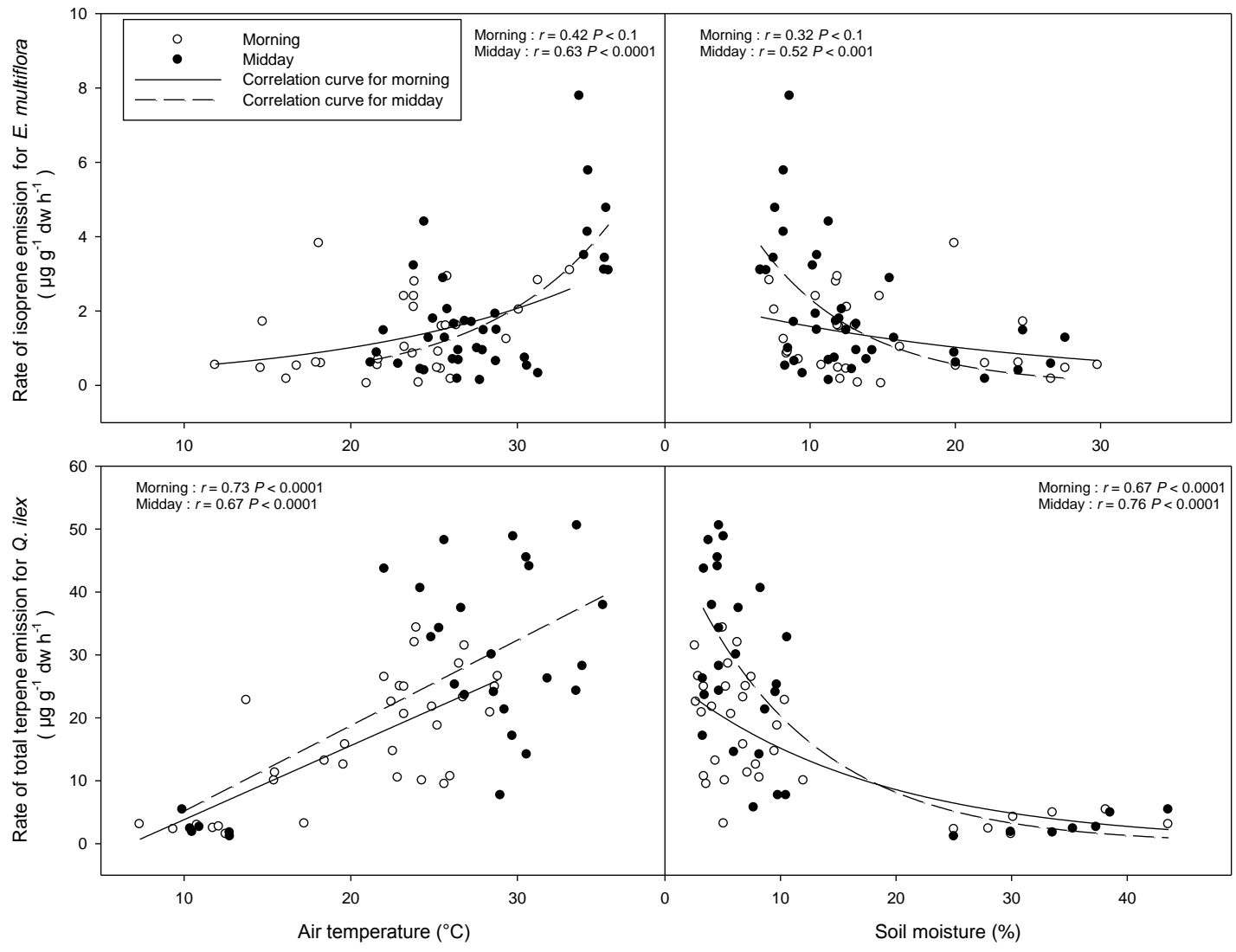

Fig. 5. Relationships for the emissions of the main isoprenoids with air temperature and soil moisture for $E$. multiflora and $Q$. ilex. 
Table 1. Relationships of main isoprenoid emissions (isoprene for E. multiflora and total terpenes for $Q$. ilex) with air temperature and soil moisture (SE, Standard Error).

\begin{tabular}{|c|c|c|c|c|c|}
\hline & & \multicolumn{2}{|c|}{ Morning } & \multicolumn{2}{|c|}{ Midday } \\
\hline & & Linear & Exponential & Linear & Exponential \\
\hline E. multiflora & $R$ & 0.3832 & 0.4187 & 0.5680 & 0.6280 \\
\hline \multirow[t]{2}{*}{ Air temperature } & $P$ & 0.0366 & 0.0213 & 0.0002 & $<0.0001$ \\
\hline & SE & 0.9875 & 0.9710 & 1.4307 & 1.3528 \\
\hline \multicolumn{2}{|c|}{ Correspondent equation } & \multicolumn{2}{|c|}{$y=0.246 * 1.074 \wedge^{\wedge} x$} & \multicolumn{2}{|c|}{$y=0.042 * 1.139 \wedge x$} \\
\hline & $R$ & 0.3125 & 0.3165 & 0.4409 & 0.5182 \\
\hline \multirow[t]{2}{*}{ Soil moisture } & $P$ & 0.0927 & 0.0884 & 0.0056 & 0.0009 \\
\hline & SE & 1.1056 & 1.0142 & 1.5603 & 1.4867 \\
\hline \multicolumn{2}{|c|}{ Correspondent equation } & \multicolumn{2}{|c|}{$y=2.449 * 0.958{ }^{\wedge} x$} & \multicolumn{2}{|c|}{$y=9.562^{*} 0.868^{\wedge} x$} \\
\hline Q. ilex & $R$ & 0.7266 & 0.6995 & 0.6701 & 0.6124 \\
\hline \multirow[t]{2}{*}{ Air temperature } & $P$ & $<0.0001$ & $<0.0001$ & $<0.0001$ & 0.0005 \\
\hline & SE & 6.9235 & 7.2012 & 12.3180 & 13.1199 \\
\hline \multicolumn{2}{|c|}{ Correspondent equation } & \multicolumn{2}{|c|}{$y=-7.936+1.176 x$} & \multicolumn{2}{|c|}{$y=-8.404+1.358 x$} \\
\hline & $R$ & 0.6664 & 0.6814 & 0.7067 & 0.7587 \\
\hline \multirow[t]{2}{*}{ Soil moisture } & $P$ & $<0.0001$ & $<0.0001$ & $<0.0001$ & $<0.0001$ \\
\hline & SE & 7.4338 & 7.2968 & 11.7636 & 10.8312 \\
\hline \multicolumn{2}{|c|}{ Correspondent equation } & \multicolumn{2}{|c|}{$y=26.83^{*} 0.945^{\wedge} x$} & \multicolumn{2}{|c|}{$y=50.66^{*} 0.913^{\wedge} x$} \\
\hline
\end{tabular}

